\title{
PROPOSED USE OF THE PLENARY POWERS TO DESIG- NATE A TYPE SPECIES FOR THE GENUS “FULGORA" LINNAEUS, 1767, AND TO SUPPRESS THE GENERIC NAME "LATERNARIA" LINNAEUS, 1764 (CLASS INSECTA, ORDER HEMIPTERA)
}

\author{
By R. G. FENNAH \\ (Imperial College of Tropical Agricultural, Trinidad)
}

\section{(Commission's reference Z.N.(S.)162)}

The object of the present application is to secure a legal foundation for the use of the generic name Fulgora Linnaeus, 1767, in its currently accepted sense. Two distinct problems are involved ; these are dealt with separately as Cases 1 and 2 respectively.

\section{Case 1}

Aim of present application: The aim of the present application is to secure that the type species of Fulgora Linnaeus, 1767, shall be Cicada laternaria Linnaeus, 1758. The relevant references are :-

(a) The generic name Fulgora Linnaeus was first published in 1767, Syst. Nat. (ed. 12) 1 (2) : 703, no. 1.

(b) Claims have been advanced on behalf of each of the following authors to be regarded as the author by whom the type species of Fulgora Linnaeus was first either designated or selected :-

(i) Linnaeus, 1767, Syst. Nat. (ed.12 1 (2) : 703: type species designated under Rule $(f)$ in Article 30: Cicada laternaria Linnaeus, 1758; Syst. Nat. (ed. 10) $1: 434$, no. 1 ;

(ii) Sulzer, 1776, Dr. Sulzers abgek. Gesch. Ins. : 85, Tab. 9, fig. 5 : type species selected under Rule $(g)$ in Article 30: Fulgora europaea Linnaeus, 1767, Syst. Nat. (ed. 12) 1 (2) : 704, no. 9 ;

(iii) Latreille, 1810, Consid. gén. Crust. Arach. Ins. : 434 : type species selected under Rule $(g)$ in Article 30, as interpreted by Opinions 11 and 136: Fulgora europaea Fabricius, 1775, Syst. Ent. : 674 (=Fulgora europaea Linnaeus, 1767).

Discussion of the case: The generic name Fulgora was published with a description but with no type designation. The following nine nominal species were placed in this genus: laternaria; diadema; candelaria; phosphorea; noctivida; lucernaria; flammea ; truncata; europaea. Two of these species, namely $F$. laternaria and $F$. candelaria, by evidence of identical description and references, belong to the genus Laternaria Linnaeus, 1764 (Mus. Lud. Ulr.: 152 ), and were the only two species included in that genus. The former is the type species of Laternaria by absolute tautonymy.

The relation of the name Fulgora Linnaeus, 1767, to Laternaria Linnaeus, 1764, must be either that of a nomen novum for a supposedly invalid Laternaria, or a simple substitution, as it cannot be a restriction of Laternaria, since it includes all the species originally placed in that genus. In his treatment of 
Cicada in 1764 (which there follows immediately after the genus Laternaria), Linnaeus did not include a single one of the species which three years later he listed under the generic name Fulgora. It is clear that what Linnaeus had decided upon and what he attempted to do with the limited material available to him in 1764 and with the fuller material available in 1767, was to erect a genus to contain the species which in 1758 he had placed in the section "Noctilucae" (capite antice protracta in vesicam oblongam) of the genus Cicada. It was merely an accident that in 1764 he did not have before him all the species which he had originally included in the "Noctilucae", namely C. laternaria, C. candelaria, C. phosphorea, C. noctivida, and C. lucernaria, the only two then at his disposal being the first two.

The generic name Laternaria was published without a description, but two nominal species were included in it, of which the first is the type species by absolute tautonymy. This generic name accordingly satisfies the requirements of Article 25 and is an available name. The name Fulgora cannot therefore be interpreted as a nomen novum for an unavailable name. It must therefore be regarded as a substitute name for Laternaria, and, as it was published without a type designation, it may be argued that, by application of Rule $(f)$ in Article 30, the genus Fulgora takes, as its type species, the type species of the genus which it replaces, namely Cicada laternaria Linnaeus, 1758.

If the foregoing contention is not upheld, it becomes necessary to examine the argument advanced by Kirkaldy in 1913 (Bull. Hawaii. Sug. Ass. (Ent. Ser.) 12:11) that Sulzer (1776) selected Fulgora europaea Linnaeus as the type species of the genus Fulgora by publishing an unambiguous figure of that species (pl. 9, fig. 5) with the following statement (: 85) :-

Wir haben in unserer Tafel die Kegelstirn nicht gewählt, als wenn sie dem Leser den vollständigsten und richtigsten Begriff von diesem Geschlechte geben könnte, sondern weil sie noch wirgends abgebildet worden, und gleichwohl nicht nur eine Europäerin, sondern wol gar eine Schweizerin ist ; wenn man aber beliebt Rösel's vorteftliche Abbildungen des grossen Laternträgers und des Kleinern, der sich in Kennzeichen Tab. X fig. $62 a$ befindet, mit dieser Beschreibung zusammen zu halten, so wird man eine genugsame Kenntniss davon erlangen. Linne beschreibt 9 Arten.*

It is considered that the foregoing action by Sulzer closely resembles the statement made by Lamarck in 1801 (Syst. Anim. sans Vertebres) regarding the purpose of citing representative species for the genera which he was then discussing. Accordingly, under the precedent set by the rejection of Lamarck's action as constituting selections of type species by the ruling given by the International Commission on Zoological Nomenclature in their Opinion 79, Sulzer's action in the present case must be rejected as insufficient to constitute a type selection for the genus Fulgora, under Rule $(g)$ in Article 30.

* The following is a translation of the passage quoted from the Sulzer (1776):-

For our plate we have not selected the Cone-Face as giving the reader the most complete and most correct idea of this genus, but a species which, although nowhere hitherto figured, is not only a European, but even a Swiss insect; but, if the reader wishes to compare Rösel's striking illustration of the large Lanternbearer which appears on plate 10, fig. 62a with this description, he will gain an adequate idea therefrom. Linnaeus described nine species. 
We have now to consider the action taken by Latreille in 1810 (Consid. gén. Crust. Arach. Ins. : 434), where he cited "Fulgora europaea Fab." as the type species of "Fulgore," which earlier (: 262) in the same work he had defined under both the French and Latin forms of this generic name ("Fulgore" and Fulgora). The species so cited by Latreille, by description, by bibliographic citation and by geographical distribution is unquestionably Fulgora europaea Linnaeus, 1767. Latreille's action in the Consid. gén. has been ruled by the International Commission on Zoological Nomenclature as constituting rigorous selections of type species for the genera there dealt with (Opinions 11 and 136) and accordingly his selection of Fulgora europaea Linnaeus as the type species of Fulgora Linnaeus must be accepted as complying with the Rules, if it is held that no type species had been designated or validly selected for that genus prior to Latreille's action in $\mathbf{1 8 1 0 .}$

It is urged however that, quite irrespective of the merits of the claims advanced on behalf of the foregoing authors to have designated or selected a type species for the genus Fulgora Linnaeus, there is strong historical reason for conserving this generic name for the species (Cicada laternaria Linnaeus) which Linnaeus considered to be luminous. By the use of such terms as laternaria (which he thought sufficiently striking to adopt from Merian), phosphorea and Fulgora, by the note which he inserted in the description regarding the alleged nocturnal luminosity of this species, and by the first place which he consistently gave to this species in all his writings on Homoptera, Linnaeus clearly revealed that his conception (1) of the Section "Noctilucae" of the genus Cicada, (2) of the genus Laternaria, and (3) of the genus Fulgora was based upon this insect and extended to other species, in so far as they possessed what he supposed to be the essential organ of luminosity, a cephalic process.

Action by the International Commission on Zoological Nomenclature desired: The International Commission on Zoological Nomenclature are asked, either, if they think it proper, to declare that Cicada laternaria Linnaeus, 1758 , is the type species of the genus Fulgora Linnaeus, 1767, under Rule $(f)$ in Article 30, or, if they do not consider this to be the case, to use their plenary powers to designate the foregoing species as the type species of this genus.

\section{Case 2}

Aim of present application: The aim of the present application is to secure the suppression, under the plenary powers of the generic name Laternaria Linnaeus, 1764, in favour of the name Fulgora Linnaeus, 1767.

Discussion of the case: With the exception of Kirkaldy and Haupt, who based their classification upon the belief that Fulgora europaea Linnaeus, 1767, was the type species of the genus Fulgora Linnaeus, 1767, students of Homoptera have universally employed the generic name Fulgora for 184 years as the generic name either of the Neotropical species Cicada laternaria Linnaeus, 1758, or of the Oriental species Cicada candelaria Linnaeus, 1758. Further, the generic name Fulgora formed the basis of the first group names to be adopted (namely Fulgorellae Latreille, 1807; Fulgoridae Leach, 1817; Fulgorina Burmeister, 1835 ; Fulgorelles, Fulgorites and Fulogoroids Spinola, $1839)$ and their later modifications. 
Scrutiny of the type designations and type selections made for the genera Laternaria Linnaeus, 1764, and Fulgora Linnaeus, 1767, strongly suggests that these genera have the same species, Cicada laternaria Linnaeus, 1767, as their respective type species and almost the universal practice of students of this group has been to treat as the type species of Fulgora the above species which certainly is the type species of Laternaria.

It is considered that in this case the application of the Law of Priority. which was designed to stabilise nomenclature, would have the opposite effect, It would lead to the suppression, as a synonym, of one of the earliest and best known generic names in zoology (Fulgora Linnaeus, 1767) and with it the series of supergeneric terms founded upon it, and would leave in its stead a name (Laternaria Linnaeus, 1764) which only students of the Hemiptera are likely to recognise and which only two or three have used as the basis of the name for a supergeneric unit. The name Fulgora Linnaeus presents a clear case of a name which should be preserved for the sake of avoiding confusion.

Action by the International Commission on Zoological Nomenclature desired: The International Commission on Zoological Nomenclature are asked (1) to use their plenary powers $(a)$ to suppress the generic name Laternaria Linnaeus, 1764, and (b) to validate the generic name Fulgora Linnaeus, 1767, and (2) to place the latter generic name (with Cicada laternaria Linnaeus, 1758, as type species) on the Official List of Generic Names in Zoology.

\section{REPORT ON THE PROPOSAL THAT THE GENERIC NAME “FULGORA" LINNAEUS, 1767 (CLASS INSECTA, ORDER HEMIPTERA) SHOULD BE VALIDATED UNDER THE PLENARY POWERS}

By FRANCIS HEMMING, C.M.G., C.B.E.

(Secretary to the International Commission on Zoological Nomenclature)

(Commission's reference Z.N.(S.)162)

Mr. R. C. Fennah has asked the International Commission on Zoological Nomenclature to use its pleanary powers to validate the generic name Fulgora Linnaeus, 1767 (Class Insecta, Order Hemiptera) and thus to avoid the serious confusion which would be likely to arise if that name were to be discarded in favour of the virtually unknown name Laternaria Linnaeus, 1764. Mr. Fennah first wrote to the Commission on this subject in August 1944. After expressing the belief that, under the Règles, Fulgora Linnaeus, 1767, was an objective synonym of Laternaria Linnaeus, 1764, the two genera having the same species as their respective type species, Mr. Fennah then pointed out that the question at issue involved not only the status of the generic name Fulgora itself for within the previous 137 years a large number of terms had been applied to units of higher taxonomic rank based upon the word " Fulgora". In this connection he cited the terms: Fulgorellae, Fulgorida, Fulgorides,

Bull. zool. Nomencl. Vol. 6, Pt. 2. September 1951 


\section{$2 \mathrm{BHL}$ Biodiversity Heritage Library}

Fennah, Ronald Gordon. 1951. "Proposed use of the plenary powers to designate a type species for the genus "Fulgora" Linnaeus 1767, and to suppress the generic name "Laternaria" Linnaeus 1764 (class insecta, order Hemiptera)." The Bulletin of zoological nomenclature 6, 34-37. https://doi.org/10.5962/bhl.part.15979.

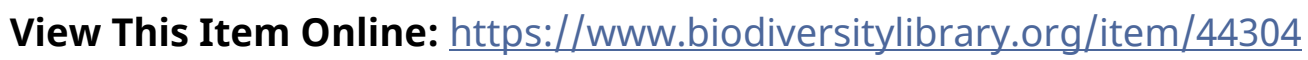

DOI: https://doi.org/10.5962/bhl.part.15979

Permalink: https://www.biodiversitylibrary.org/partpdf/15979

\section{Holding Institution}

Natural History Museum Library, London

\section{Sponsored by}

Natural History Museum Library, London

\section{Copyright \& Reuse}

Copyright Status: In copyright. Digitized with the permission of the rights holder.

License: http://creativecommons.org/licenses/by-nc-sa/3.0/

Rights: https://biodiversitylibrary.org/permissions

This document was created from content at the Biodiversity Heritage Library, the world's largest open access digital library for biodiversity literature and archives. Visit BHL at https://www.biodiversitylibrary.org. 